\title{
Inflammatory response of endothelial cells to hepatitis $C$ virus recombinant envelope glycoprotein 2 protein exposure
}

\author{
Ana Carolina Urbaczek ${ }^{1 /+}$, Lívia Carolina de Abreu Ribeiro', Valdecir Farias Ximenes ${ }^{2}$, \\ Ana Afonso $^{3,4,5}$, Camila Tita Nogueira ${ }^{1}$, Wesley Cardoso Generoso ${ }^{6}$, Juliana Vieira Alberice ${ }^{5}$, \\ Martina Rudnicki ${ }^{7}$, Renila Ferrer ${ }^{7}$, Luiz Marcos da Fonseca', Paulo Inácio da Costa ${ }^{1}$
}

\begin{abstract}
1'Laboratório de Imunologia Clínica, Departamento de Análises Clínicas, Escola de Ciências Farmacêuticas ${ }^{2}$ Departamento de Química, Faculdade de Ciências, Universidade Estadual Paulista Julio de Mesquita Filho, Bauru, SP, Brasil ${ }^{3}$ Departamento de Parasitologia Médica, Unidade de Parasitologia Médica e Microbiologia, Instituto de Higiene e Medicina Tropcal, Universidade Nova de Lisboa, Lisboa, Portugal ${ }^{4}$ Departamento de Morfologia e Patologia ${ }^{6}$ Departamento de Genética e Evolução, Universidade Federal de São Carlos, São Carlos, SP, Brasil ${ }^{5}$ Grupo de Bioanalítica, Microfabricações e Separações, Departamento de Química e Física Molecular, Instituto de Química de São Carlos, Universidade de São Paulo, São Carlos, SP, Brasil ${ }^{7}$ Escola de Ciências Farmacêuticas, Universidade de São Paulo, São Paulo, SP, Brasil
\end{abstract}

The hepatitis $C$ virus (HCV) encodes approximately 10 different structural and non-structural proteins, including the envelope glycoprotein 2 (E2). HCV proteins, especially the envelope proteins, bind to cell receptors and can damage tissues. Endothelial inflammation is the most important determinant of fibrosis progression and, consequently, cirrhosis. The aim of this study was to evaluate and compare the inflammatory response of endothelial cells to two recombinant forms of the HCV E2 protein produced in different expression systems (Escherichia coli and Pichia pastoris). We observed the induction of cell death and the production of nitric oxide, hydrogen peroxide, interleukin-8 and vascular endothelial growth factor A in human umbilical vein endothelial cells (HUVECs) stimulated by the two recombinant E2 proteins. The E2-induced apoptosis of HUVECs was confirmed using the molecular marker PARP. The apoptosis rescue observed when the antioxidant $\mathrm{N}$-acetylcysteine was used suggests that reactive oxygen species are involved in E2-induced apoptosis. We propose that these proteins are involved in the chronic inflammation caused by $\mathrm{HCV}$.

Key words: HCV - E2 protein - inflammation - HUVEC

The hepatitis $\mathrm{C}$ virus (HCV), a member of the genus Hepacivirus in the family Flaviviridae, is a small enveloped virus that possesses a positive-sense singlestranded RNA genome of approximately $9.6 \mathrm{~kb}$ (Hoofnagle 2002, Penin et al. 2004, Kaukinen et al. 2013). The genome has a single open reading frame (ORF) (Taylor et al. 2000) encoding a polyprotein precursor of approximately 3,000 amino acid residues that is cleaved by host and viral proteases to generate approximately 10 distinct structural and non-structural proteins (Encke et al. 1998, Penin et al. 2004). One of these proteins is envelope glycoprotein 2 (E2), which undergoes post-translational modification after synthesis and possesses nine-11 potential glycosylation sites (Liu et al. 2001, Whidby et al. 2009). The E2 glycoprotein plays fundamental roles in the initiation of infection at different stages of the replication cycle, including receptor binding, fusion with the host cell membrane and invasion (Bartenschlager \& Lohmann 2000, Bartosch et al. 2003, Dubuisson et al. 2008, Lin et al. 2009).

\footnotetext{
doi: 10.1590/0074-0276140090

Financial support: FUNDECIF, FAPESP (2008/58957-0)

+ Corresponding author: anaurba@yahoo.com.br

Received 11 March 2014

Accepted 29 July 2014
}

HCV infects approximately 170 million individuals, representing $3 \%$ of the world's population (Bian et al. 2009, Burke \& Cox 2010, Ruggieri et al. 2013). The World Health Organization estimates that three-four million individuals are infected worldwide every year (Seeff \& Hoofnagle 2003). The persistence of the infection and the severity of the resultant inflammation can lead to chronic hepatitis complicated by cirrhosis and/ or hepatocellular carcinoma (Ghany et al. 2003, Balasubramanian et al. 2005, Burke \& Cox 2010, Kaukinen et al. 2013), making HCV infection one of the most prevalent liver diseases in the world today. HCV infection is responsible for $60 \%$ of chronic liver diseases and is the major indication for liver transplants (Lauer \& Walker 2001, Whidby et al. 2009).

However, intra-hepatic inflammation appears to be more important than direct viral cytotoxicity in the development of progressive liver injury. Several studies have reported that intra-hepatic inflammation, especially lobular and/or periportal inflammation, is an important determinant of the progression of fibrosis (Zeremski et al. 2007). The cause of endothelial pathology is not well defined, but some hypotheses suggest that several factors may contribute to the inflammatory process, such as nitric oxide (NO), which causes a potential inflammatory lesion in the tissue and increases the expression of chemokines [e.g., interleukin-8 (IL-8)], cytokines and endothelial adhesion molecules, thus amplifying the inflammation cascade (Remick \& Villarete 1996, Wald et 
al. 2007). Furthermore, it is believed that HCV proteins, especially the envelope proteins, can be toxic to cells independent of direct viral infection by producing the "innocent bystander" effect (Balasubramanian et al. 2005).

The vascular changes in the cirrhotic livers of patients with chronic hepatitis $\mathrm{C}$ have attracted increasing interest because little is known about their relationship with major complications, such as portal hypertension, liver failure and hepatocellular carcinoma; thus, little is known about the prognostic implications of these vascular changes, highlighting the need for a more detailed characterisation of the inflammatory aspects in this scenario. Therefore, the aim of this study was to evaluate and compare the inflammatory response of endothelial cells [human umbilical vein endothelial cells (HUVECs)] to two recombinant forms of the HCV E2 protein produced in different expression systems.

\section{SUBJECTS, MATERIALS AND METHODS}

Strains, cell lines and media - Escherichia coli DH5a (Invitrogen, USA) was used for the general propagation of plasmids and E. coli BL21 (DE3) was used to express the E2 protein. Bacterial cells were grown under agitation at $37^{\circ} \mathrm{C}$ in a low-salt Luria-Bertani medium containing Zeocin at a final concentration of $25 \mu \mathrm{g} / \mathrm{mL}$. Pichia pastoris $\mathrm{KM} 71 \mathrm{H}^{\left(\mathrm{Mut}^{\mathrm{s}}\right)}$ (Invitrogen) was used as the expression host. Yeast cultures were maintained in a yeast extract-peptone-dextrose (YEPD) medium. The media for growth and induction were buffered complex glycerol medium (BMGY) and buffered complex methanol medium (BMMY), respectively, both at pH 4.0 HUVECs (ATCC ${ }^{\circledR}$ CRL-2873 ${ }^{\mathrm{TM}}$ ) were grown in RPMI-1640 medium (Sigma Aldrich, USA) containing 10\% foetal bovine serum and a mix of antibiotics and antifungals (Sigma Aldrich). The cultures were kept at $37^{\circ} \mathrm{C}$ and $5 \% \mathrm{CO}_{2}$ and disassociated from the culture dish using trypsin.

Cloning, expression and purification of 22 protein in E. coli - HCV cDNA was obtained from viral RNA extracted with the QIAmp Viral RNA Mini Kit (QIAGEN, USA), according to the manufacturer's protocol, using pooled sera from individuals with HCV genotype la provided by the Laboratory of Clinical Immunology of the Pharmaceutical Science School of Araraquara, São Paulo, Brazil. The HCV sequence was found by comparison using the BLASTn local alignment program and its ORF was entirely sequenced. To express recombinant E2 protein, the soluble form of the protein without the transmembrane domain was selected (residues 384-661). The mature ORF was amplified with the forward primer 5'-GGCCATGGGGGAAACCCACGTCACCGG-3' and reverse primer 5'-GCTCGAGGCTCGGACCTGTCCCTGTC-3' (the underlined bases indicate introduced restriction sites for $\mathrm{NcOI}$ and $\mathrm{XhoI}$, respectively) (Rodríguez-Rodríguez et al. 2009). The pET42a plasmid was used to generate the mature E2 protein ORF flanked by glutathione S-transferase (GST) at the N-terminus and a $6 \mathrm{x}$ His tag at the C-terminus. The transformed $E$. coli BL21 were induced for $3 \mathrm{~h}$ with isopropylthio- $\beta$ galactoside (final concentration $0.4 \mathrm{mM}$ ) at $37^{\circ} \mathrm{C}$ and 250 $\mathrm{rpm}$ when the optical density (OD) at $600 \mathrm{~nm}$ reached
0.5 . The cells were pelleted, suspended in lysis buffer $(10$ $\mathrm{mM}$ Tris- $\mathrm{HCl}, 50 \mathrm{mM} \mathrm{NaH} \mathrm{PO}_{4}$ and $100 \mathrm{mM} \mathrm{NaCl}, \mathrm{pH}$ 8.0 ) and subjected to sonication (5 pulses of $1 \mathrm{~min}$ each). The soluble phase was purified using Glutathione Sepharose 4 Fast Flow (GE Healthcare, USA). The binding buffer employed was $10 \mathrm{mM}$ Tris-base, $50 \mathrm{mM}$ sodium phosphate and $100 \mathrm{mM}$ sodium chloride at $\mathrm{pH}$ 8.0. The GST-tagged protein was eluted with a two-fold resin volume of elution buffer $(10 \mathrm{mM}$ reduced glutathione and 50 $\mathrm{mM}$ Tris-HCl, $\mathrm{pH} 8.0$ ). The fractions containing the purified protein were dialysed against phosphate-buffered saline (PBS) (pH 8.0), quantified using the Pierce ${ }^{\mathrm{TM}} \mathrm{BCA}$ protein assay kit (Thermo Scientific, USA) and stored at $-20^{\circ} \mathrm{C}$. This protein is referred to as E2B in this work.

Cloning, expression and purification of recombinant protein in P. pastoris - The E2 protein ORF was cloned into pPICZ $\alpha$ A and the mature ORF was amplified with the forward primer 5'-AAGAATTCGAAACCCACGTCACCGGGGGAA-3' and the reverse primer 5'AATCTAGATTCTCGGACCTGTCCCTGTCTTCC-3' (the underlined bases indicate introduced EcoRI and $X b a I$ restriction sites, respectively). The cloning was performed to create a recombinant plasmid containing the E2 protein ORF flanked by the secretion signal peptide ( $\alpha$-factor) at the $\mathrm{N}$-terminus and a 6x His tag at the C-terminus. Before P. pastoris transformation, the recombinant plasmid was linearised with $P m e I$ endonuclease and introduced into the yeast by electroporation $(1.5 \mathrm{kV}, 25 \mu \mathrm{F}, 200 \Omega)$ (Cregg 2007). Transformants were cultivated in solid YEPD with $1 \mathrm{M}$ sorbitol and $100 \mu \mathrm{g} /$ $\mathrm{mL}$ Zeocin. The yeast transformants were screened for protein induction in 24-well plates (Boettner et al. 2002). One recombinant yeast colony was selected for protein production and purification. Expression induction for protein purification was performed as described in Generoso et al. (2012), differing only in the use of BMGY and BMMY medium buffered with $100 \mathrm{mM}$ McIlvaine's buffer, $\mathrm{pH}$ 4.0. The supernatant was dialysed against PBS buffer ( $\mathrm{pH}$ 8.0), concentrated using the Labscale TFF System (membrane Pellicon XL50, Millipore, USA) until 10 -fold reduction and stored at $-20^{\circ} \mathrm{C}$. This protein is referred to as E2Y in this work.

Cell viability - For the determination of cell viability, HUVECs were seeded at $5 \times 10^{5}$ cells $/ \mathrm{mL}$. The adherent cells were incubated for $24 \mathrm{~h}$ at $37^{\circ} \mathrm{C}$ and $5 \% \mathrm{CO}_{2}$ with the recombinant proteins (E2B and $\mathrm{E} 2 \mathrm{Y}$ ) at 250,125 , $62.5,31.25,15.63$ and $7.81 \mu \mathrm{g} / \mathrm{mL}$ or with $1.0 \mu \mathrm{g} / \mathrm{mL}$ lipopolysaccharide (LPS), $10 \mathrm{ng} / \mathrm{mL}$ tumour necrosis factor alpha (TNF- $\alpha$ ), $10 \%$ sodium dodecyl sulfate (SDS) (positive controls) or RPMI medium and the culture supernatant of $E$. coli BL21 cells (negative controls). After incubation, the cells were incubated with 3-(4, 5-dimethylthiazol-2-yl)-2,5-diphenyltetrazolium bromide $(1 \mathrm{mg} /$ $\mathrm{mL}$ ) for $3 \mathrm{~h}$. The resultant formazan salt was dissolved in acidic 2-propanol and the OD was measured (540/620 $\mathrm{nm}$ filters). The OD of the untreated cells was taken as $100 \%$ cell viability (Mosmann 1983). The experiments were performed in triplicate. 
Cell death - HUVECs were seeded at $5 \times 10^{4}$ cells/ $\mathrm{mL}$ and incubated for $24 \mathrm{~h}$ at $37^{\circ} \mathrm{C}$ and $5 \% \mathrm{CO}_{2}$ with recombinant $\mathrm{E} 2 \mathrm{~B}$ and $\mathrm{E} 2 \mathrm{Y}$ using the concentrations and controls as described in the Cell viability section. The following controls were also added: cells without stimulation (negative) and annexin and propidium iodide (PI) controls. The evaluation of cell death was performed using the Annexin V-FITC Annexin V Apoptosis Detection Kit (BD Pharmingen, USA) according to the manufacturer's protocol. The cells were analysed by flow cytometry (using a FACSCanto flow cytometer, $\mathrm{BD}$ Biosciences and FACSDiva software v.6.1.3). In each run, 30,000 cells were analysed and all experiments were performed in triplicate.

$N$-acetylcysteine (NAC) treatment - The effect of NAC on cells exposed to E2 recombinant proteins was studied with respect to apoptosis (PARP cleavage) and $\mathrm{NO}$ and hydrogen peroxide $\left(\mathrm{H}_{2} \mathrm{O}_{2}\right)$ production. HUVECs were pre-incubated with $5 \mathrm{mM} \mathrm{NAC}$ for $1 \mathrm{~h}$ and treated with E2Y, E2B and controls as described above.

PARP cleavage - HUVECs at $5 \times 10^{5}$ cells $/ \mathrm{mL}$ were pre-incubated in the presence or absence of NAC (5 $\mathrm{mM}$ ) for $1 \mathrm{~h}$ and incubated for $24 \mathrm{~h}$ at $37^{\circ} \mathrm{C}$ and $5 \% \mathrm{CO}_{2}$ with recombinant $\mathrm{E} 2$ proteins (E2B and $\mathrm{E} 2 \mathrm{Y}$ ) using the concentrations and control stimuli described in the Cell viability section. HUVECs were lysed in $10 \mathrm{mM}$ Tris (pH 7.4), 1 mM EDTA, 0.5 mM EGTA, $150 \mathrm{mM} \mathrm{NaCl}$, $1 \%$ Triton X-100, $50 \mathrm{mM} \mathrm{NaF}, 10 \mathrm{mM} \mathrm{Na}_{4} \mathrm{P}_{2} \mathrm{O}_{7} \cdot 10 \mathrm{H}_{2} \mathrm{O}, 5$ $\mu \mathrm{g} / \mathrm{mL}$ aprotinin, $5 \mu \mathrm{g} / \mathrm{mL}$ leupeptin and $1 \mathrm{mM}$ PMSF. To evaluate cell apoptosis, $20 \mu \mathrm{g}$ of lysate protein was electrophoresed in 8\% SDS-polyacrylamide gels and transferred onto nitrocellulose membranes (Hybond ECL). The membranes were blocked with 5\% skim milk in Tris-buffered saline (TBS) containing $0.1 \%$ Tween- 20 (TBS-T) and subsequently incubated with rabbit PARP antibody (1:2000 dilution, Santa Cruz Biotechnology, Inc, USA) overnight at $4^{\circ} \mathrm{C}$ to detect full-length PARP $(116 \mathrm{kDa})$ and cleaved PARP (carboxyl-terminal catalytic fragment, $89 \mathrm{kDa}$ ). After washing with TBS-T for $1 \mathrm{~h}$ at room temperature (RT), the membranes were further incubated with a horseradish peroxidase-conjugated rabbit polyclonal antibody (1:2000 dilution; Santa Cruz Biotechnology, Inc) for $2 \mathrm{~h}$ followed by $1 \mathrm{~h}$ washing (with 3-5 wash buffer changes). Protein bands were visualised with signal reagents. Actin levels were used to control for protein levels and were detected with an antibody against actin (Yang et al. 2004).

NO production - Total NO production was determined in the culture supernatant of HUVECs seeded at $5 \times 10^{4}$ cells/mL incubated with E2B and E2Y and controls as described in the Cell viability section for $24 \mathrm{~h}$ at $37^{\circ} \mathrm{C}$ and $5 \% \mathrm{CO}_{2}$. The samples were measured in a $\mathrm{NO}$ analyser (Sievers Nitric Oxide Analyzer Overview, model NOA 280i, GE Analytical Instruments, USA), in which the nitrites, nitrates and nitrosothiols present in the supernatant were converted into NO by a saturated solution of vanadium trichloride in $0.8 \mathrm{M} \mathrm{HCl}$ at $90^{\circ} \mathrm{C}$. $\mathrm{NO}$ was detected by a chemiluminescent reaction in the gas phase between NO and ozone (Archer 1993, Jaiswal et al. 2000).
Arginase activity - Arginase activity was measured using urea. This reaction is based on L-arginine hydrolysis by arginase in cell lysates (Corraliza et al. 1994). Briefly, HUVECs were cultured with recombinant proteins, LPS, TNF- $\alpha$ and culture medium or culture supernatant of $E$. coli BL21 cells using the concentrations and stimuli described in the Cell viability section. The cells were lysed using $100 \mu \mathrm{L}$ of $0.1 \%$ Triton X-100 for $30 \mathrm{~min}$ under agitation. Subsequently, $50 \mu \mathrm{L}$ of cell lysate was added to $50 \mu \mathrm{L}$ of $25 \mathrm{mM}$ Tris- $\mathrm{HCl}$ and $25 \mu \mathrm{L}$ of $100 \mathrm{mM}$ $\mathrm{MnCl}_{2}$ and the final solution was incubated for $10 \mathrm{~min}$ at $56^{\circ} \mathrm{C}$ for enzyme activation. Next, $50 \mu \mathrm{L}$ of $0.5 \mathrm{M} \mathrm{L}$ arginine ( $\mathrm{pH}$ 9.7) was added and the test reaction was incubated at $37^{\circ} \mathrm{C}$ for $60 \mathrm{~min}$. The reaction was stopped by adding $400 \mu \mathrm{L}$ of Stop Solution $\left(96 \% \mathrm{H}_{2} \mathrm{SO}_{4}, 85 \% \mathrm{H}_{3} \mathrm{PO}_{4}\right.$ and water, at a proportion of 1:3:7 v/v/v). Twenty-five microlitres of $9 \% \alpha$-isonitrosopropiophenone in $100 \%$ ethanol was added and the reaction was incubated at $95^{\circ} \mathrm{C}$ for $30 \mathrm{~min}$. Finally, the cells were incubated at RT for $10 \mathrm{~min}$ and the absorbance was measured using a $540 \mathrm{~nm}$ filter. The urea concentration was calculated using a linear equation generated by known quantities of urea. One unit of enzyme activity was defined as the amount of enzyme capable of producing $1 \mu \mathrm{mol}$ of urea per minute.

$\mathrm{H}_{2} \mathrm{O}_{2}$ production - HUVECs at $5 \times 10^{5}$ cells $/ \mathrm{mL}$ were incubated for $2 \mathrm{~h}$ at $37^{\circ} \mathrm{C}$ and $5 \% \mathrm{CO}_{2}$ with recombinant E2B and E2Y using the concentrations and stimuli described in the Cell viability section. Approximately 600 $\mathrm{ng} / \mathrm{mL}$ dihydrorhodamine 123 (DHR) (Sigma-Aldrich) was added and the cells were incubated at $37^{\circ} \mathrm{C}$ for 10 min. The cells were washed with PBS (pH 7.2) and centrifuged for $5 \mathrm{~min}$ at $300 \mathrm{~g}$. The supernatant was discarded and the cells were resuspended in $150 \mu \mathrm{L}$ of PBS ( $\mathrm{pH}$ 7.2). The samples were read in the FL1 channel using a FACSCanto flow cytometer (BD Biosciences) and FACSDiva software v.6.1.3. The experiment included a control for spontaneous fluorescence (cells only) and a control for spontaneous production of $\mathrm{H}_{2} \mathrm{O}_{2}$ (DHR and cells without stimuli) (Walrand et al. 2003).

$I L-8, T N F-\alpha$ and vascular endothelial growth factor A (VEGF-A) production - HUVECs at $5 \times 10^{4}$ cells $/ \mathrm{mL}$ were incubated for $24 \mathrm{~h}$ at $37^{\circ} \mathrm{C}$ and $5 \% \mathrm{CO}_{2}$ with recombinant E2B and E2Y using the concentrations and controls described in the Cell viability section. An additional control using PMA $(0.50 \mu \mathrm{M})$ was used in the TNF- $\alpha$ detection assay. The negative control consisted of $300 \mu \mathrm{L}$ of culture medium and $300 \mu \mathrm{L}$ of PBS (pH 7.2; medium of the protein dilution). Supernatants were collected and centrifuged at $2,860 \mathrm{~g}$ and $4^{\circ} \mathrm{C}$ for $10 \mathrm{~min}$. IL-8, TNF- $\alpha$ and VEGF-A production was measured by ELISA using the kit Human VEGF-A Platinum ELISA (eBioscience Inc, USA), according to the manufacturer's instructions. Cytokine concentrations were calculated using a cytokine calibration curve. The results are expressed in $\mathrm{pg} / \mathrm{mL}$.

Statistical analysis - The data were analysed by ANOVA using a 5\% level of significance followed by multiple comparisons with the Tukey test and graphic representation of the data. The statistical program GraphPad v.5.00 (GraphPad Software, USA) was used. Values of $\mathrm{p}<0.05$ were considered significant. 


\section{RESULTS}

The recombinant E2 proteins were expressed in two different expression systems, the $E$. coli Rosetta strain (E2B) and the P. pastoris KM71 $\mathrm{H}^{\left(\mathrm{Mut} \mathrm{s}^{\mathrm{s}}\right)}$ strain (E2Y) (Fig. 1). The E2B protein exhibited a molecular weight of approximately $63.5 \mathrm{kDa}$ due to its expression as a fusion protein with GST $(26 \mathrm{kDa})$ and the $6 \mathrm{x}$ His tag $(1 \mathrm{kDa})$. The E2Y protein exhibited a molecular weight of approximately $50.0 \mathrm{kDa}$ due to its expression as a fusion protein with the 6x His tag $(1 \mathrm{kDa})$. The $\mathrm{N}$-glycosylation of the E2Y protein was confirmed by protein treatment with a peptide-N-glycosidase, PNGase F (New England Biolabs, USA), according to the manufacturer's protocol. The proteins exhibited different molecular weights $(\mathrm{E} 2 \mathrm{~B}=36.5 \mathrm{kDa}$ and $\mathrm{E} 2 \mathrm{Y}=49 \mathrm{kDa})$ due to the types of protein processing used in these two systems.

We observed that some concentrations of the recombinant E2 proteins (E2Y: $62.5-250 \mu \mathrm{g} / \mathrm{mL}$ and E2B: $125-$ $250 \mu \mathrm{g} / \mathrm{mL}$ ) were slightly cytotoxic to HUVECs (Fig. 2). At $250 \mu \mathrm{g} / \mathrm{mL}$, the decrease in viability was similar to that obtained when the cells were incubated with LPS or TNF- $\alpha$. The cellular events provoked by the E2 proteins were evaluated using annexin V and PI assays, which indicated that early apoptosis was the main cause of cell death (Fig. 3). However, even at the highest concentration of E2 protein used in this study, the proportion of apoptotic cells was always lower than $30 \%$.

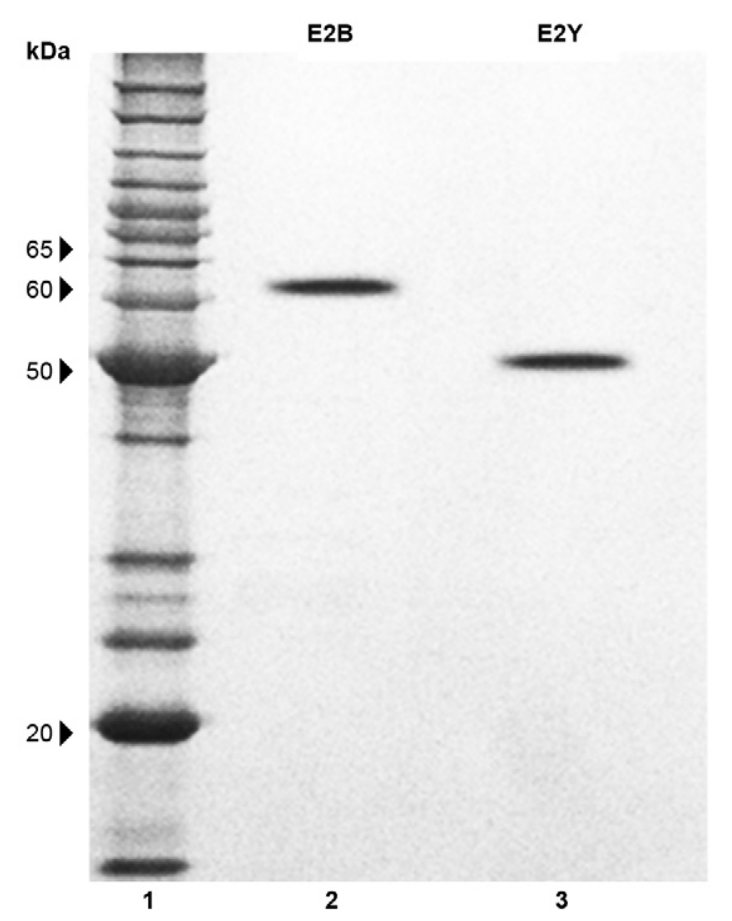

Fig. 1: produced envelope glycoprotein 2 (E2) recombinant proteins (sodium dodecyl sulfate polyacrylamide gel electrophoresis $12 \%$ ). Channel 1: molecular weight marker [BenchMark ${ }^{\mathrm{TM}}$ Protein Ladder (10-220 kDa), Invitrogen]; 2: E2B (approximately $63.5 \mathrm{kDa}) ; 3$ : E2Y (approximately $50 \mathrm{kDa}$ ).

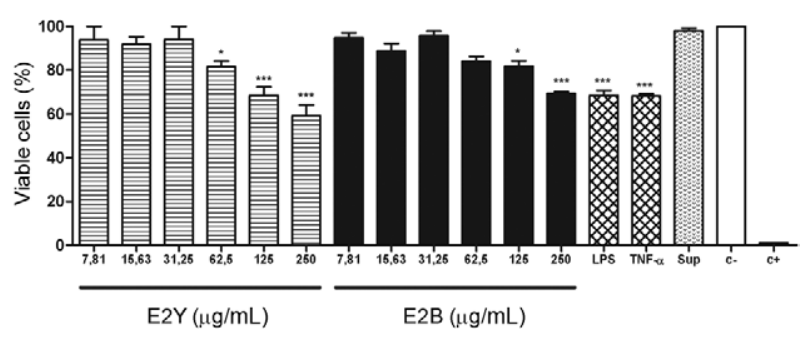

Fig. 2: effect of envelope glycoprotein 2 (E2) recombinant proteins on human umbilical vein endothelial cells viability [3-(4, 5-dimethylthiazol-2-yl)-2,5-diphenyltetrazolium bromide assay]. Results are expressed as mean and standard deviation of viable cells. The experiments were performed in triplicate. c-: negative control; c+: culture medium RPMI; LPS: lipopolysaccharide $(1.0 \mu \mathrm{g} / \mathrm{mL})$; Sup: culture supernatant Escherichia coli BL21; TNF- $\alpha$ : tumour necrosis factor alpha $(10 \mathrm{ng} / \mathrm{mL}) ; *: \mathrm{p}<0.05$ compared to the negative control; ***: $\mathrm{p}$ $<0.001$ compared to the negative control.

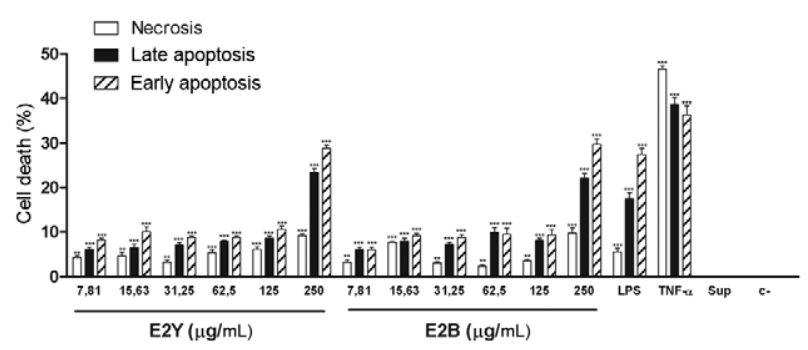

Fig. 3: cytotoxicity of envelope glycoprotein 2 (E2) proteins on human umbilical vein endothelial cells. Results presented as mean and standard deviation of percentage obtained in the assay. In each run, 30,000 cells were analysed and all experiments were performed in triplicate. c-: negative control; early apoptosis: annexin $\mathrm{V}$ stained cells; late apoptosis: cells double-positive for annexin $\mathrm{V}$ and propidium iodide (PI); LPS: lipopolysaccharide $(1.0 \mu \mathrm{g} / \mathrm{mL})$; necrosis: cells stained with PI; Sup: culture supernatant Escherichia coli BL21; TNF- $\alpha$ : tumour necrosis factor alpha $(10 \mathrm{ng} / \mathrm{mL}) ; * * *: \mathrm{p}<0.001 \mathrm{com}-$ pared to the negative control.

To further explore the mechanism of E2 proteininduced apoptosis, we investigated the degradation of PARP, which is thought to be one of the targets of activated caspase-3 or 7 during apoptosis (Yang et al. 2004). Immunoblot analysis revealed that the recombinant $\mathrm{E} 2$ proteins induced the degradation of endogenous $116 \mathrm{kDa}$ PARP, as shown by the appearance of $89 \mathrm{kDa}$ fragments (Fig. 4A, B), which were clearly detected in all samples treated with E2 protein or with the control stimuli, TNF- $\alpha$ (Fig. 4E, Line1) and LPS (Fig. 4E, Line 3). These results indicate that PARP cleavage is associated with E2-induced apoptosis in HUVECs. Moreover, the pretreatment of the cells with the antioxidant NAC protected against apoptosis by preventing PARP cleavage (Fig. $4 \mathrm{C}, \mathrm{D})$. The same effect was observed for the TNF- $\alpha$ (Fig. 4E, Line 2) and LPS (Fig. 4E, Line 4) controls.

The production of NO by HUVECs was stimulated by E2 protein treatments (Fig. 5). Statistical analysis of the results revealed that there was a statistically significant difference $(\mathrm{p}<0.01)$ when compared with the spontaneous control (negative control) or production stimu- 


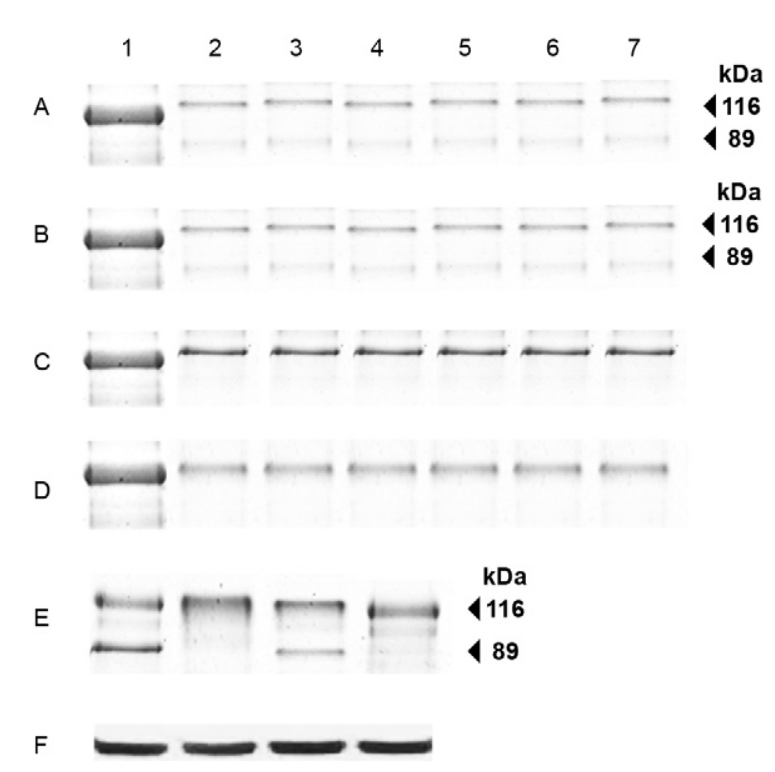

Fig. 4: PARP cleavage in recombinant envelope glycoprotein 2 (E2)induced apoptosis in human umbilical vein endothelial cells. Cells were pre-treated (C, D) or no (A, B) with $N$-acetylcysteine (NAC) for $1 \mathrm{~h}$ and incubated with recombinant E2 proteins, E2Y (A, C) and E2B $(\mathrm{B}, \mathrm{D})$ in different concentrations. The experiments were performed in triplicate. Line 2: $7.81 \mu \mathrm{g} / \mathrm{mL} ; 3: 15.63 \mu \mathrm{g} / \mathrm{mL} ; 4: 31.25 \mu \mathrm{g} / \mathrm{mL} ; 5$ : $62.5 \mu \mathrm{g} / \mathrm{mL} ; 6: 125 \mu \mathrm{g} / \mathrm{mL}$; $7: 250 \mu \mathrm{g} / \mathrm{mL}$; A-D1: lysate of untreated cells; E1: cells without pre-treatment with NAC and treated with tumour necrosis factor alpha (TNF- $\alpha$ ); E2: cells pre-treated with NAC and treated with TNF- $\alpha$; E3: cells without pre-treatment with NAC and treated with lipopolysaccharide (LPS); E4: cells pre-treated with NAC and treated with LPS; F1-4: actin.

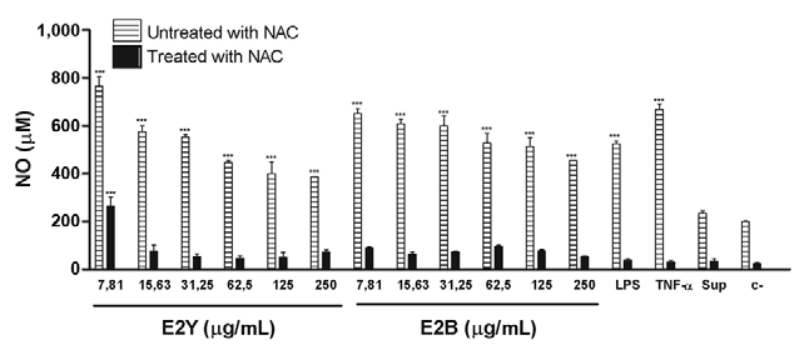

Fig. 5: nitric oxide (NO) production by envelope glycoprotein 2 (E2)stimulated human umbilical vein endothelial cells. Results are expressed as mean and standard deviation of NO produced in $\mu \mathrm{M}$. The experiments were performed in triplicate. c-: NO spontaneous production, cells and culture medium; LPS: lipopolysaccharide $(1.0 \mu \mathrm{g} /$ $\mathrm{mL}$ ); NAC: $N$-acetylcysteine; Sup: culture supernatant Escherichia coli BL21; TNF- $\alpha$ : tumour necrosis factor alpha $(10 \mathrm{ng} / \mathrm{mL}) ; * * *: \mathrm{p}<$ 0.001 compared to the negative control.

lated by the bacterial supernatant. The E2 proteins were as effective as the classical stimuli, LPS and TNF- $\alpha$. One exception was the treatment with $7.81 \mu \mathrm{g} / \mathrm{mL}$ of E2 protein, in which only a slight, but significant elevation in NO was observed relative to the more potent LPS and TNF- $\alpha$ stimuli. The higher production of NO was not the result of increased or decreased arginase activity relative to the negative control (result not shown) because no

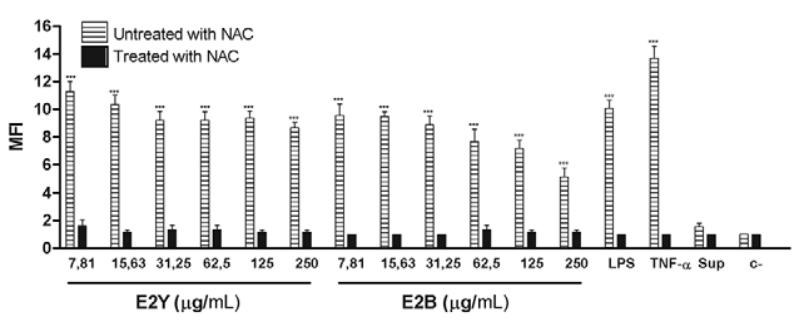

Fig. 6: hydrogen peroxide production by envelope glycoprotein 2 (E2)-stimulated human umbilical vein endothelial cells. Results presented as mean and standard deviation of the mean fluorescence intensity (MFI). The experiments were performed in triplicate. c-: control fluorescence spontaneous, cells without stimulation; LPS: 1ipopolysaccharide $(1.0 \mu \mathrm{g} / \mathrm{mL})$; NAC: $N$-acetylcysteine; Sup: culture supernatant Escherichia coli BL21; TNF- $\alpha$ : tumour necrosis factor alpha $(10 \mathrm{ng} / \mathrm{mL}) ; * *: \mathrm{p}<0.001$ in relation to negative control.

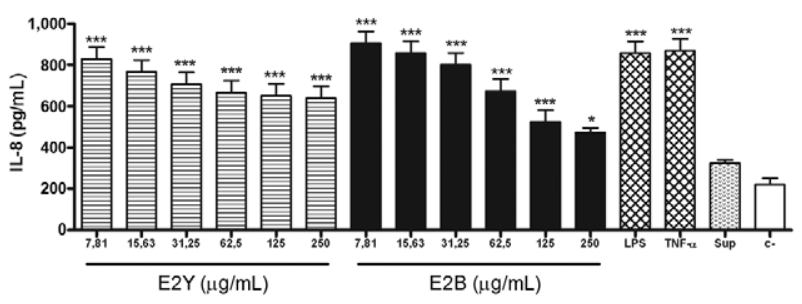

Fig. 7: interleukin-8 (IL-8) production by envelope glycoprotein 2 (E2)-stimulated human umbilical vein endothelial cells. Results presented as mean and standard deviation. The experiments were performed in triplicate. c-: cells and medium and phosphate-buffered saline ( $\mathrm{pH}$ 7.2). LPS: lipopolysaccharide $(1.0 \mu \mathrm{g} / \mathrm{mL})$; Sup: culture supernatant Escherichia coli BL21; TNF- $\alpha$ : tumour necrosis factor alpha $(10 \mathrm{ng} / \mathrm{mL}) ; * * *: \mathrm{p}<0.001$ compared to negative control; *: $\mathrm{p}<$ 0.05 compared to negative control.

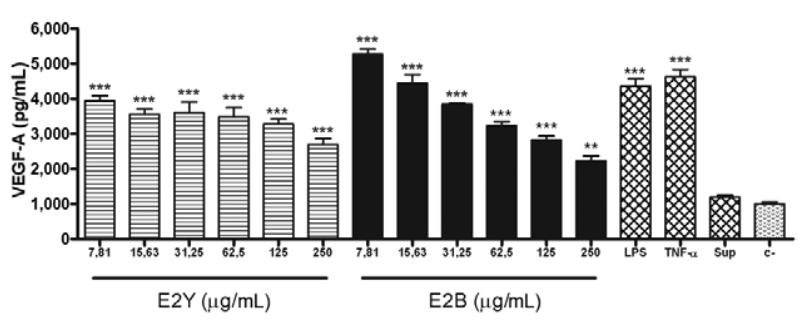

Fig. 8: vascular endothelial growth factor A (VEGF-A) production by envelope glycoprotein 2 (E2)-stimulated human umbilical vein endothelial cells. Results presented as mean and standard deviation. The experiments were performed in triplicate. LPS: lipopolysaccharide $(1.0 \mu \mathrm{g} / \mathrm{mL})$; TNF- $\alpha$ : tumour necrosis factor alpha $(10 \mathrm{ng} / \mathrm{mL})$; Sup: culture supernatant Escherichia coli BL21; c-: cells and medium and phosphate-buffered saline ( $\mathrm{pH} 7.2)$; **: $\mathrm{p}<0.01$ compared to the negative control; $* * * \mathrm{p}<0.001$ compared to the negative control.

significant differences were observed when compared with the negative control. Our data also demonstrated that pre-treatment with NAC significantly decreased ( $\mathrm{p}$ $<0.01)$ the $\mathrm{E} 2$ protein-induced $\mathrm{NO}$ production.

The production of $\mathrm{H}_{2} \mathrm{O}_{2}$ was evaluated in HUVECs after exposure to recombinant proteins at different concentrations and control stimuli. The relative production of $\mathrm{H}_{2} \mathrm{O}_{2}$, calculated as the mean fluorescence intensity, is 
presented in Fig. 6. The E2 proteins were able to stimulate the production of $\mathrm{H}_{2} \mathrm{O}_{2}$ at all of the tested concentrations. Again, the production was similar to that obtained by stimulation with LPS and was inferior to that of TNF- $\alpha$. Of the two E2 proteins, E2Y was more effective than E2B at concentrations of $7.81 \mu \mathrm{g} / \mathrm{mL}(p<0.05)$. The results of pre-treatment with NAC revealed a significant decrease $(\mathrm{p}<0.01)$ in the $\mathrm{E} 2$ protein-induced $\mathrm{H}_{2} \mathrm{O}_{2}$ production.

The E2 proteins were capable of inducing the production of IL-8 compared with non-stimulated cells. The detection of IL-8 production by HUVECs is presented in Fig. 7. There was a statistically significant difference $(p<0.05)$ between all of the stimuli tested compared with the negative control. Unlike the IL-8 results, the E2 proteins were not able to induce the production of TNF- $\alpha$ or LPS by HUVECs. However, $0.50 \mu \mathrm{M}$ PMA induced HUVECs to produce $173.05 \mathrm{pg} / \mathrm{mL}$ TNF- $\alpha$.

The detection of VEGF-A production by HUVECs in response to control stimuli and recombinant proteins is presented in Fig. 8. The E2 proteins significantly induced $(p<0.01)$ the production of VEGF-A by HUVECs.

The E2 protein-induced production of $\mathrm{NO}, \mathrm{H}_{2} \mathrm{O}_{2}$, IL-8 and VEGF by HUVECs strongly supports the cytotoxicity of these proteins.

\section{DISCUSSION}

There is evidence that endothelial cells are directly susceptible to infection by HCV (Fletcher et al. 2012) and that the damage caused by the infection leads to late complications, such as fibrosis, cirrhosis and hepatocellular carcinoma. These late complications are believed to be caused by numerous inflammatory molecules in response to viral infection of the liver (Ming-Ju et al. 2011). Consistent with this hypothesis, we found that E2 proteins were able to induce apoptosis and several inflammatory responses in HUVECs. The putative receptors for E2 proteins in this cellular type have been described previously, including low-density lipoprotein receptor (Agnello et al. 1999), tetraspanin CD81 (Zhang et al. 2004), scavenger receptor class B type 1 (Scarselli et al. 2002), claudin-1 (Evans et al. 2007), occludin (OCLN) (Ploss et al. 2009) and transferrin receptor 1 (TfR1) (Martin \& Uprichard 2013).

NO is an inorganic free radical molecule (Furchgott \& Zawadzki 1980) that is highly diffusible and reactive (Bredt \& Snyder 1992) and is involved in various physiological functions and pathological conditions when produced in excess (Kaufman 1999, Benali-Furet et al. 2005, Deshpande et al. 2012). As a chronic inflammatory disease, hepatitis $\mathrm{C}$ induces an increase in NO production (Kane et al. 1997), which may play an important role in the pathogenesis of cirrhosis associated with infection (Hassan et al. 2002). Here, we have demonstrated for the first time that NO production by HUVECs was induced by both recombinant E2 proteins. This NO production may lead to later inflammation in the portal vein and subsequent fibrosis and cirrhosis.

The increased NO production could be the consequence of the increased expression of arginase in HUVECs. HCV infection is associated with the development of hepatocellular carcinoma (Okuda 2007, Tan et al. 2008) and can alter the expression of arginase, thereby stimulating tumourigenesis and hepatocellular carcinoma (Cao et al. 2009). However, this pathway does not appear to be relevant to endothelial cells because arginase expression was not altered by the $\mathrm{E} 2$ proteins.

The E2 proteins were also able to induce the production of $\mathrm{H}_{2} \mathrm{O}_{2}$ by HUVECs. This is additional evidence of the role of E2 in the inflammatory response mediated by $\mathrm{HCV}$. This result is consistent with the findings of Ming$\mathrm{Ju}$ et al. (2011) and suggests the involvement of the E2 protein in $\mathrm{H}_{2} \mathrm{O}_{2}$ production and the development of inflammation in the hepatic portal vein, with the increased expression of factors related to hepatic fibrosis.

Balasubramanian et al. (2003) reported that the HCV E2 protein was able to stimulate intracellular signalling pathways, leading to the induction of secretion of proinflammatory cytokine IL-8. The authors also reported that this production was dose-dependent. IL-8 is also observed in the serum of patients with chronic hepatitis C (Polyak et al. 2001, Akbar et al. 2011), demonstrating a correlation between inflammation, IL-8 serum levels and liver fibrosis (Kaplanski et al. 1997, Mahmood et al. 2002). These findings are evidence that IL-8 may play a role in HCV infection. Consistent with this hypothesis, recombinant E2 proteins stimulated the production of IL-8 in HUVECs. These results are consistent with the work of Balasubramanian et al. (2005). However, the E2 proteins were not able to induce the production of TNF- $\alpha$ by HUVECs. These results are also consistent with the work of Balasubramanian et al. (2005), who reported that HCV proteins can interact with the endothelium and that E2 protein did not induce the production of cytokines such as monocyte chemotactic protein-1, TNF- $\alpha$ and gamma interferon.

Analysis of peripheral blood mononuclear cells and liver biopsy samples of individuals chronically infected by the virus suggests that $\mathrm{HCV}$ infection may be able to induce apoptosis, causing damage to the liver while helping the virus to evade the immune system and facilitate viral dissemination (Hiramatsu et al. 1994, Pianko et al. 2001, Chiou et al. 2006). Here, we found that the E2 proteins were also able to induce apoptosis (early and late) as well as necrosis (fewer cells) in HUVECs. Similar results were also observed by Balasubramanian et al. (2005). The glycosylated protein expressed in P. pastoris (E2Y) was a more effective inducer of apoptosis as well as necrosis relative to the non-glycosylated protein (E2B), demonstrating the influence of glycosylation on apoptosis. The E2-induced apoptosis of HUVECs was confirmed using the molecular marker PARP. Moreover, the apoptosis induced by recombinant E2 protein was effectively rescued in cells pre-treated with NAC, suggesting that the generation of reactive oxygen species is involved in E2-induced apoptosis in HUVECs. We also suggest that the production of $\mathrm{NO}, \mathrm{H}_{2} \mathrm{O}_{2}$, IL-8 and VEGF-A were not related to cell death induced by high concentrations of the recombinant protein, but are E2-specific effects.

VEGF-A is a potent angiogenic factor that plays a key role in the development of angiogenesis in various tumour types (Toi et al. 2000), including hepatocellular carcinoma (Ng et al. 2001, Poon et al. 2004). VEGF-A has a specific angiogenic effect on endothelial cells 
and can be stimulated by HCV infection (Dvorak et al. 1992). Additionally, VEGF-A plays a role in the regulation of several cellular functions, including growth (Nasimuzzaman et al. 2007) and apoptosis (Höglinger et al. 2007). This effect was observed by Hassan et al. (2009) in liver biopsy samples of patients infected with HCV. Hepatic angiogenesis has been described in viral hepatitis, autoimmune liver cirrhosis, primary biliary cirrhosis and hepatocellular carcinoma (García-Monzón et al. 1995, Ker et al. 1999). HCV stimulates the synthesis and secretion of VEGF-A via virus-induced oxidative stress (Nasimuzzaman et al. 2007). In our study, the exposure of HUVECs to both recombinant E2 proteins induced the production of VEGF-A. We suggest that oxidative stress, as demonstrated by the production of $\mathrm{NO}$ and $\mathrm{H}_{2} \mathrm{O}_{2}$ in HUVECs in response to E2 proteins, may represent the stimulating factor of VEGF-A production. The literature reports that the $\mathrm{HCV}$ core protein is able to stimulate the production of VEGF-A, but there are no data regarding the E2 protein (Hassan et al. 2004, Abe et al. 2012). Therefore, this is the first demonstration that the E2 protein is also able to induce the production of VEGF-A and, consequently, angiogenesis.

$\mathrm{HCV}$ is a positive-stranded RNA virus that is unable to integrate its genetic material into the host cell genome. The HCV genome does not contain oncogenes, suggesting that $\mathrm{HCV}$ induces hepatocellular carcinoma indirectly by causing chronic inflammation, cell death, proliferation and cirrhosis (Hassan et al. 2009). Here, we provide evidence that endothelial cells, such as HUVECs, are susceptible to E2 HCV envelope proteins.

In conclusion, stimulation with E2 protein induced HUVECs to produce inflammatory and angiogenic factors. Considering that endothelial inflammation is a determinant of fibrosis progression and cirrhosis, we propose that these cellular effects might be involved in the persistence and chronicity of HCV infection. These results may contribute to our understanding of the pathophysiology of hepatitis $\mathrm{C}$ and, consequently, to the development of new therapeutic strategies against the interaction of HCV structural proteins and the hepatic endothelium.

\section{ACKNOWLEDGEMENTS}

To Prof Flávio Henrique da Silva, for allowing the use of his laboratory in UFSCar and for providing equipment, reagents and protocols for the production of recombinant proteins, to Prof Iracilda Zeppone Carlos, for providing many of the materials used in this research, as well as equipment from her laboratory (School of Pharmaceutical Sciences of Araraquara, UNESP), to Prof Dulcinéia Saes Parra Abdalla (School of Pharmaceutical Sciences, USP), for the donation of HUVEC, to Marisa Polezi Placeres (School of Pharmaceutical Sciences of Araraquara, UNESP), for technical assistance in cell culture, and to Prof Fernanda Anibal (UFSCar), for assistance in this paper revision.

\section{REFERENCES}

Abe M, Koga H, Yoshida T, Masuda H, Iwamoto H, Sakata M, Hanada S, Nakamura T, Taniguchi E, Kawaguchi T, Yano H, Torimura T, Ueno T, Sata M 2012. Hepatitis C virus core protein upregulates the expression of vascular endothelial growth factor via the nuclear factor- $\mathrm{\kappa} \mathrm{B} / \mathrm{hyp}$ poxia-inducible factor- $1 \alpha$ axis under hypoxic conditions. Hepatol Res 42: 591-600.
Agnello V, Abel G, Elfahal M, Knight GB, Zhang QX 1999. Hepatitis $\mathrm{C}$ virus and other Flaviviridae viruses enter cells via low density lipoprotein receptor. Proc Natl Acad Sci USA 96: 12766-12771.

Akbar H, Idrees M, Butt S, Awan Z, Sabar MF, Rehaman I, Hussain A, Saleem S 2011. High baseline interleukin-8 level is an independent risk factor for the achievement of sustained virological response in chronic HCV patients. Infect Genet Evol 11: 1301-1305.

Archer S 1993. Measurement of nitric oxide in biological models. FASEB J 7: 349-360.

Balasubramanian A, Ganju RK, Groopman JE 2003. Hepatitis C virus and HIV envelope proteins collaboratively mediate interleukin- 8 secretion through activation of p38 MAP kinase and SHP2 in hepatocytes. J Biol Chem 278: 35755-35766.

Balasubramanian A, Munshi N, Koziel MJ, Hu Z, Liang TJ, Groopman JE, Ganju RK 2005. Structural proteins of hepatitis C virus induce interleukin 8 production and apoptosis in human endothelial cells. J Gen Virol 86: 3291-3301.

Bartenschlager R, Lohmann V 2000. Replication of hepatitis C virus. $J$ Gen Virol 81: 1631-1648.

Bartosch B, Dubuisson J, Cosset FL 2003. Infectious hepatitis C virus pseudo-particles containing functional E1-E2 envelope protein complexes. J Exp Med 197: 633-642.

Benali-Furet NL, Chami M, Houel L, De Giorgi F, Vernejoul F, Lagorce D, Buscail L, Bartenschlager R, Ichas F, Rizzuto R, Paterlini-Bréchot $\mathrm{P}$ 2005. Hepatitis $\mathrm{C}$ virus core triggers apoptosis in liver cells by inducing ER stress and ER calcium depletion. Oncogene 24: 4921-4933.

Bian T, Zhou Y, Bi S, Tan W, Wang Y 2009. HCV envelope protein function is dependent on the peptides preceding the glycoproteins. Biochem Biophys Res Commun 378: 118-122.

Boettner M, Prinz B, Holz C, Stahl U, Lang C 2002. High-throughput screening for expression of heterologous proteins in the yeast $P i$ chia pastoris. J Biotechnol 99: 51-62.

Bredt DS, Snyder SH 1992. Nitric oxide, a novel neuronal messenger. Neuron 8: 3-11.

Burke KP, Cox AL 2010. Hepatitis C virus evasion of adaptive immune responses: a model for viral persistence. Immunol Res 47: 216-227.

Cao W, Sun B, Feitelson MA, Wu T, Tur-Kaspa R, Fan Q 2009. Hepatitis $\mathrm{C}$ virus targets over-expression of arginase $\mathrm{I}$ in hepatocarcinogenesis. Int J Cancer 124: 2886-2892.

Chiou HL, Hsieh YS, Hsieh MR, Chen TY 2006. HCV E2 may induce apoptosis of Huh-7 cells via a mitochondrial-related caspase pathway. Biochem Biophys Res Commun 345: 453-458.

Corraliza IM, Campo ML, Soler G, Modolell M 1994. Determination of arginase activity in macrophages: a micromethod. $J$ Immunol Methods 174: 231-235.

Cregg JM 2007. Pichia protocols, 2nd ed., Humana Press, Totowa, $268 \mathrm{pp}$.

Deshpande SR, Satyanarayana K, Rao MN, Pai KV 2012. Nitric oxide modulators: an emerging class of medicinal agents. Indian $J$ Pharm Sci 74: 487-497.

Dubuisson J, Helle F, Cocquerel L 2008. Early steps of the hepatitis C virus life cycle. Cell Microbiol 10: 821-827.

Dvorak HF, Nagy JA, Berse B, Brown LF, Yeo KT, Yeo TK, Dvorak AM, van de Water L, Sioussat TM, Senger DR 1992. Vascular permeability factor, fibrin and the pathogenesis of tumor stroma formation. Ann N Y Acad Sci 667: 101-111.

Encke J, zu Putlitz J, Heintges T, Wands JR 1998. Total chemical synthesis of the 3' untranslated region of the hepatitis $C$ virus with long oligodeoxynucleotides. J Virol Methods 74: 117-121. 
Evans MJ, von Hahn T, Tscherne DM, Syder AJ, Panis M, Wölk B, Hatziioannou T, McKeating JA, Bieniasz PD, Rice CM 2007. Claudin-1 is a hepatitis C virus co-receptor required for a late step in entry. Nature 446: 801-805.

Fletcher NF, Wilson GK, Murray J, Hu K, Lewis A, Reynolds GM, Stamataki Z, Meredith LW, Rowe IA, Luo G, Lopez-Ramirez MA, Baumert TF, Weksler B, Couraud PO, Kim KS, Romero IA, Jopling C, Morgello S, Balfe P, McKeating JA 2012. Hepatitis $\mathrm{C}$ virus infects the endothelial cells of the blood-brain barrier. Gastroenterology 142: 634-643.

Furchgott RF, Zawadzki JV 1980. The obligatory role of endothelial cells in the relaxation of arterial smooth muscle by acetylcholine. Nature 288: 373-376.

García-Monzón C, Sánchez-Madrid F, García-Buey L, García-Arroyo A, García-Sánchez A, Moreno-Otero R 1995. Vascular adhesion molecule expression in viral chronic hepatitis: evidence of neoangiogenesis in portal tracts. Gastroenterology 108: 231-241.

Generoso WC, Malagó-Jr W, Pereira N, Henrique-Silva F 2012. Recombinant expression and characterization of an endoglucanase III (cel12a) from Trichoderma harzianum (Hypocreaceae) in the yeast Pichia pastoris. Genet Mol Res 11: 1544-1557.

Ghany MG, Kleiner DE, Alter H, Doo E, Khokar F, Promrat K, Herion D, Park Y, Liang TJ, Hoofnagle JH 2003. Progression of fibrosis in chronic hepatitis C. Gastroenterology 124: 97-104.

Hassan M, Ghozlan H, Abdel-Kader O 2004. Activation of RB/E2F signaling pathway is required for the modulation of hepatitis $\mathrm{C}$ virus core protein-induced cell growth in liver and non-liver cells. Cell Signal 16: 1375-1385.

Hassan M, Selimovic D, Ghozlan H, Abdel-kader O 2009. Hepatitis C virus core protein triggers hepatic angiogenesis by a mechanism including multiple pathways. Hepatology 49: 1469-1482.

Hassan MI, Kassim SK, Ali HS, Sayed el-DA, Khalifa A 2002. Evaluation of nitric oxide (NO) levels in hepatitis $\mathrm{C}$ virus (HCV) infection: relationship to schistosomiasis and liver cirrhosis among Egyptian patients. Dis Markers 18: 137-142.

Hiramatsu N, Hayashi N, Katayama K, Mochizuki K, Kawanishi Y, Kasahara A, Fusamoto H, Kamada T 1994. Immunohistochemical detection of Fas antigen in liver tissue of patients with chronic hepatitis C. Hepatology 19: 1354-1359.

Höglinger GU, Breunig JJ, Depboylu C, Rouaux C, Michel PP, Alvarez-Fischer D, Boutillier AL, Degregori J, Oertel WH, Rakic P, Hirsch EC, Hunot S 2007. The pRb/E2F cell-cycle pathway mediates cell death in Parkinson's disease. Proc Natl Acad Sci USA 104: 3585-3590.

Hoofnagle JH 2002. Course and outcome of hepatitis C. Hepatology 36 (Suppl. 1): S21-S29.

Jaiswal M, La Russo NF, Burgart LJ, Gores GJ 2000. Inflammatory cytokines induce DNA damage and inhibit DNA repair in cholangiocarcinoma cells by a nitric oxide-dependent mechanism. Cancer Res 60: 184-190.

Kane JM, Shears LL, Hierholzer C, Ambs S, Billiar TR, Posner MC 1997. Chronic hepatitis $C$ virus infection in humans: induction of hepatic nitric oxide synthase and proposed mechanisms for carcinogenesis. J Surg Res 69: 321-324.

Kaplanski G, Farnarier C, Payan MJ, Bongrand P, Durand JM 1997. Increased levels of soluble adhesion molecules in the serum of patients with hepatitis C. Correlation with cytokine concentrations and liver inflammation and fibrosis. Dig Dis Sci 42: 2277-2284.

Kaufman RJ 1999. Stress signaling from the lumen of the endoplasmic reticulum: coordination of gene transcriptional and translational controls. Genes Dev 13: 1211-1233.
Kaukinen P, Sillanpää M, Nousiainen L, Melén K, Julkunen I 2013. Hepatitis $C$ virus NS2 protease inhibits host cell antiviral response by inhibiting IKK $\varepsilon$ and TBK1 functions. J Med Virol 85: 71-82.

Ker CG, Chen HY, Juan CC, Lo HW, Shen YY, Chen JS, Lee KT, Sheen PC 1999. Role of angiogenesis in hepatitis and hepatocellular carcinoma. Hepatogastroenterology 46: 646-650.

Lauer GM, Walker BD 2001. Hepatitis C virus infection. $N$ Engl $J$ Med 345: 41-52.

Lin X, Zhang Y, Bi S, Lu J, Zhao H, Tan W, Li D, Wang Y 2009. Hepatitis $\mathrm{C}$ virus envelope glycoproteins complementation patterns and the role of the ecto and transmembrane domains. Biochem Biophys Res Commun 385: 257-262.

Liu J, Zhu L, Zhang X, Lu M, Kong Y, Wang Y, Li G 2001. Expression, purification, immunological characterization and application of Escherichia coli-derived hepatitis C virus E2 proteins. Biotechnol Appl Biochem 34: 109-119.

Mahmood S, Sho M, Yasuhara Y, Kawanaka M, Niiyama G, Togawa $\mathrm{K}$, Ito T, Takahashi N, Kinoshita M, Yamada G 2002. Clinical significance of intrahepatic interleukin-8 in chronic hepatitis $\mathrm{C}$ patients. Hepatol Res 24: 413-419.

Martin DN, Uprichard SL 2013. Identification of transferrin receptor 1 as a hepatitis C virus entry factor. Proc Natl Acad Sci USA 110: 10777-10782.

Ming-Ju H, Yih-Shou H, Tzy-Yen C, Hui-Ling C 2011. Hepatitis C virus $\mathrm{E} 2$ protein induce reactive oxygen species (ROS)-related fibrogenesis in the HSC-T6 hepatic stellate cell line. J Cell Biochem 112: 233-243.

Mosmann T 1983. Rapid colorimetric assay for cellular growth and survival: application to proliferation and cytotoxicity assays. $J$ Immunol Methods 65: 55-63.

Nasimuzzaman M, Waris G, Mikolon D, Stupack DG, Siddiqui A 2007. Hepatitis C virus stabilizes hypoxia-inducible factor 1alpha and stimulates the synthesis of vascular endothelial growth factor. J Virol 81: 10249-10257.

Ng IO, Poon RT, Lee JM, Fan ST, Ng M, Tso WK 2001. Microvessel density, vascular endothelial growth factor and its receptors Flt-1 and Flk-1/KDR in hepatocellular carcinoma. Am J Clin Pathol 116: 838-845.

Okuda H 2007. Hepatocellular carcinoma development in cirrhosis. Best Pract Res Clin Gastroenterol 21: 161-173.

Penin F, Dubuisson J, Rey FA, Moradpour D, Pawlotsky JM 2004. Structural biology of hepatitis C virus. Hepatology 39: 5-19.

Pianko S, Patella S, Ostapowicz G, Desmond P, Sievert W 2001. Fasmediated hepatocyte apoptosis is increased by hepatitis $\mathrm{C}$ virus infection and alcohol consumption and may be associated with hepatic fibrosis: mechanisms of liver cell injury in chronic hepatitis C virus infection. $J$ Viral Hepat 8: 406-413.

Ploss A, Evans MJ, Gaysinskaya VA, Panis M, You H, de Jong YP, Rice CM 2009. Human occludin is a hepatitis C virus entry factor required for infection of mouse cells. Nature 457: 882-886.

Polyak SJ, Khabar KS, Rezeiq M, Gretch DR 2001. Elevated levels of interleukin-8 in serum are associated with hepatitis $\mathrm{C}$ virus infection and resistance to interferon therapy. $J$ Virol 75: 6209-6211.

Poon RT, Ho JW, Tong CS, Lau C, Ng IO, Fan ST 2004. Prognostic significance of serum vascular endothelial growth factor and endostatin in patients with hepatocellular carcinoma. Br J Surg 91: 1354-1360.

Remick DG, Villarete L 1996. Regulation of cytokine gene expression by reactive oxygen and reactive nitrogen intermediates. $J$ Leukoc Biol 59: 471-475.

Rodríguez-Rodríguez M, Tello D, Yélamos B, Gómez-Gutiérrez J, Pacheco B, Ortega S, Serrano AG, Peterson DL, Gavilanes F 
2009. Structural properties of the ectodomain of hepatitis $\mathrm{C}$ virus E2 envelope protein. Virus Res 139: 91-99.

Ruggieri A, Anticoli S, Nencioni L, Sgarbanti R, Garaci E, Palamara AT 2013. Interplay between hepatitis C virus and redox cell signaling. Int J Mol Sci 14: 4705-4721.

Scarselli E, Ansuini H, Cerino R, Roccasecca RM, Acali S, Filocamo G, Traboni C, Nicosia A, Cortese R, Vitelli A 2002. The human scavenger receptor class $\mathrm{B}$ type $\mathrm{I}$ is a novel candidate receptor for the hepatitis C virus. EMBO J 21: 5017-5025.

Seeff LB, Hoofnagle JH 2003. Appendix: The National Institutes of Health Consensus Development Conference Management of Hepatitis C 2002. Clin Liver Dis 7: 261-287.

Tan A, Yeh SH, Liu CJ, Cheung C, Chen PJ 2008. Viral hepatocarcinogenesis: from infection to cancer. Liver Int 28: 175-188.

Taylor DR, Shi ST, Lai MM 2000. Hepatitis C virus and interferon resistance. Microbes Infect 2: 1743-1756.

Toi M, Bando H, Kuroi K 2000. The predictive value of angiogenesis for adjuvant therapy in breast cancer. Breast Cancer 7: 311-314.
Wald O, Weiss ID, Galun E, Peled A 2007. Chemokines in hepatitis $\mathrm{C}$ virus infection: pathogenesis, prognosis and therapeutics. Cytokine 39: 50-62.

Walrand S, Valeix S, Rodriguez C, Ligot P, Chassagne J, Vasson MP 2003. Flow cytometry study of polymorphonuclear neutrophil oxidative burst: a comparison of three fluorescent probes. Clin Chim Acta 331: 103-110.

Whidby J, Mateu G, Scarborough H, Demeler B, Grakoui A, Marcotrigiano J 2009. Blocking hepatitis $\mathrm{C}$ virus infection with recombinant form of envelope protein 2 ectodomain. J Virol 83: 11078-11089.

Yang Y, Zhao S, Song J 2004. Caspase-dependent apoptosis and -independent poly(ADP-ribose) polymerase cleavage induced by transforming growth factor beta1. Int J Biochem Cell Biol 36: 223-234.

Zeremski M, Petrovic LM, Talal AH 2007. The role of chemokines as inflammatory mediators in chronic hepatitis $\mathrm{C}$ virus infection. $J$ Viral Hepat 14: 675-687.

Zhang J, Randall G, Higginbottom A, Monk P, Rice CM, McKeating JA 2004. CD81 is required for hepatitis $\mathrm{C}$ virus glycoproteinmediated viral infection. $J$ Virol 78: 1448-1455. 